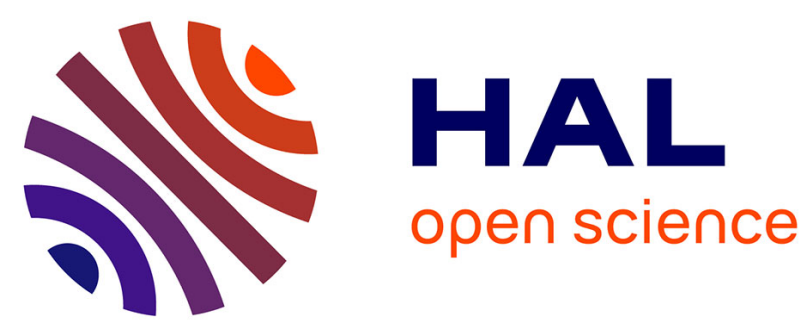

\title{
A new stonefly species (Plecoptera: Perlodidae) from Eocene Baltic amber and questions on the wing venation potential for species diagnostic of fossil Plecoptera
} Corentin Jouault, Frédéric Legendre, Fabien L. Condamine, André Nel

\section{- To cite this version:}

Corentin Jouault, Frédéric Legendre, Fabien L. Condamine, André Nel. A new stonefly species (Plecoptera: Perlodidae) from Eocene Baltic amber and questions on the wing venation potential for species diagnostic of fossil Plecoptera. Palaeoentomology, 2021, 4 (3), pp.243-256. 10.11646/palaeoentomology.4.3.12 . insu-03272797

HAL Id: insu-03272797 https://hal-insu.archives-ouvertes.fr/insu-03272797

Submitted on 28 Jun 2021

HAL is a multi-disciplinary open access archive for the deposit and dissemination of scientific research documents, whether they are published or not. The documents may come from teaching and research institutions in France or abroad, or from public or private research centers.
L'archive ouverte pluridisciplinaire HAL, est destinée au dépôt et à la diffusion de documents scientifiques de niveau recherche, publiés ou non, émanant des établissements d'enseignement et de recherche français ou étrangers, des laboratoires publics ou privés. 


\section{A new stonefly species (Plecoptera: Perlodidae) from Eocene Baltic amber and questions on the wing venation potential for species diagnostic of fos- sil Plecoptera.}

CORENTIN JOUAULT ${ }^{1,2}$, FRÉDÉRIC LEGENDRE², FABIEN L. CONDAMINE², ANDRE NEL²

1Univ. Rennes, CNRS, Geosciences Rennes, UMR 6118, F-35000, Rennes, France. E-mail: jouaultc0@gmail.com, orcid.org/0000-0002-3680-5172

2Institut de Systématique, Évolution, Biodiversité (ISYEB) Muséum national d'Histoire naturelle, CNRS, Sorbonne Université, EPHE, Université des Antilles, CP50, 57 rue Cuvier 75005 Paris, France. E-mails: frederic.legendre@mnhn.fr, https://orcid.org/0000-0001-5900-8048; anel@mnhn.fr, orcid.org/0000-0002-4241-7651

3CNRS, UMR 5554 Institut des Sciences de l'Evolution de Montpellier, Place Eugène Bataillon, 34095, Montpellier, France. E-mail: fabien.condamine@gmail.com, https://orcid.org/ 0000-0003-1673-9910

\footnotetext{
Abstract

Examination of Baltic amber Plecoptera reveals a new species of Isoperla namely: Isoperla baltica sp. nov. The placement of this new species is supported by an in-depth comparison of apomorphies supporting families, subfamilies, and suborders. Contrary to previous descriptions of many fossil species, we took advantage of the good preservation of the genitalia to describe and compare this new species to its extant congeners. Finally, we discuss the usefulness and limitations of relying on wing venation to identify diagnostic characters in Plecoptera by figuring a new specimen of
} 
Pteroliriope sinitshenkovae Cui, Béthoux, Kondratieff, Shih \& Ren, 2016 with numerous crossveins and an original organization of forewing veins.

Keywords: Springflies, Systellognatha, Arctoperlaria, fossil record, plasticity

\section{Introduction}

The Plecoptera, or stoneflies, are a numerically minor order of insects with a relatively rich fossil record (http://fossilworks.org). The oldest stem-Plecoptera are dated back to the Westphalian (ca. 314.6 to $311.45 \mathrm{Ma}$ ) from the Yanghugou Formation of China (Béthoux et al., 2011), and from France (ca. 308 to $306 \mathrm{Ma}$; Schubnel et al., 2019). The stem-Plecoptera fossil record is relatively diverse with numerous species described from the Permian (e.g. Sinitshenkova, 1987; Lin, 1992; van Dijk \& Geertsema, 2004) but some recent time-calibrated phylogenies (e.g. Misof et al., 2014; Wang et al., 2016) seem to underestimate their origin with dating estimates from the Middle Permian. The latest molecular phylogenetic analysis of the Polyneoptera supports a sister group relationships of the Plecoptera with a clade that would comprise all the other polyneopteran orders except the more inclusive clade (Zoraptera + Dermaptera) (Wipfler et al., 2019: fig. 1). This hypothesis is more consistent with the fossil record since the superorders Archaeorthoptera and Dictyoptera have a fossil record dating back to the Late Carboniferous. To improve dating estimates on the origin of the order Plecoptera, tip-dating or total-evidence dating should be used to take full advantage of their fossil record, as it has recently been done for several other groups, (e.g., Coccomorpha: Vea \& Grimaldi, 2016; Hymenoptera: Ronquist et al., 2021; Isoptera: Jouault et al., 2021; Hymenoptera Ichneumonidae: Spasojevic et al., 2021).

Numerous extant families are ancient lineages that arose during the Triassic and Jurassic but they have a relatively scarce fossil record (http://fossilworks.org). In fact, most of the fossil species described from the deep past (viz. Carboniferous and Permian) belong to extinct families, described 
from fragmentary or poorly preserved specimens and mainly on the basis of their wing venation (Sinitshenkova, 2018), whose variability could be problematic (Béthoux et al., 2011).

Currently, the Plecoptera are divided in two suborders comprising extant and fossil representatives, namely the Antarctoperlaria Zwick, 1973 and the Arctoperlaria Zwick, 1973, plus the Permian suborder Perlopseina Martynov, 1940 (e.g. Martynov, 1940; Zwick, 2000). The fossil record of each suborder is largely unequal, with more than 30 and 270 species for Antarctoperlaria and Arctoperlaria, respectively, and only three species for Perlopseina (data compiled from http://fossilworks.org; last accessed in March 27, 2021).

The Perlodidae is a relatively recent family with its oldest representative described from the Khaya Formation (Russian Federation) and dated back to the Upper Jurassic (Sinitshenkova, 1992). The fossil record of the family is scarce with only four known fossil species: Derancheperla collaris Sinitshenkova, 1990; Isoperla succinica (Hagen, 1856); Isoperlodes perstrictus Sinitshenkova, 1992; Perlodes resinatus (Hagen, 1856). The holotype specimens of $I$. succinica and P. resinatus are apparently lost (Caruso \& Wichard, 2010: 95) and their original descriptions too succinct to allow consistent comparisons, and letting us assume that they have to be treated as incertae sedis.

In this study, we describe a new species of Perlodidae based on a well-preserved male specimen from the Eocene Baltic amber. We also discuss the utility of wing venation for the diagnosis of fossil Plecoptera.

\section{Material and methods}

The Baltic amber deposits derive from a wide geographical area along the shores of the Baltic Sea, and even encompass the shores of eastern England and Scotland in their widest acceptance (Weitschat \& Wichard, 2010). The main deposits are found on or near the shores of the eastern Baltic Sea, particularly on the Samland Peninsula. Baltic amber predominantly occurs in the Blue Earth Formation (or Blue Earth member of the Prussian Formation), which was dated as late Bar- 
tonian to Priabonian (Upper Eocene, ca. 34-38 Ma) based on palynological data (Aleksandrova \& Zaporozhets, 2008; Kosmoswska-Ceranowicz et al., 1997). An older Lutetian age (ca. 41-48 Ma) of the Blue Earth Formation was suggested based on the dating of its glauconite content (Ritzkowski, 1997), but this method can give overestimated ages (Clauer et al., 2005). Smaller amounts of amber also occur in the older Lower Blue Earth Formation (Lutetian) as well as in younger Oligocene sediments. However, Oligocene amber may correspond to re-deposited Eocene material (Standke, 2008).

Altogether, this converges toward a late Eocene age for most of the fossiliferous Baltic amber (i.e. that from the Blue Earth layers), leading to an estimated age range between 34 and $38 \mathrm{Ma}$ (Priabonian), which is adopted here, although an older Lutetian age cannot be excluded for at least some amber pieces. Further discussions on the age, geological setting, and paleobiota of Baltic amber can be found in Weitschat \& Wichard (2010) and Sadowski et al. (2017).

The specimen belongs to the $19^{\text {th }}$ century Baltic amber collection of the MNHN, Paris. Its exact origin is unknown. Specimen examination was conducted under a Nikon SMZ25 stereomicroscope and pictures were taken with a Nikon D800. Stacked images were processed with Nikon Capture NXD and Helicon Focus 6.7. The figures were composed with Adobe Illustrator CC 2019 and Adobe Photoshop CC 2019 software. The amber piece was polished to facilitate the examination of the specimen using a grinder polisher (Buehler EcoMet 30) and very thin silicon carbide sanding paper (grit size $=7000$ ) or a diamond disk. The specimens presented here are housed in the collection of the Palaeontological collection of the Muséum National d'Histoire Naturelle in Paris (MNHN.F) respectively under the collection number MNHN.F.A71350 (Isoperla baltica sp. nov.) and MNHN.F.A71351 (Pteroliriope sinitshenkovae). Wing venation nomenclature follows Béthoux (2005).

Published work and nomenclatural acts are registered in ZooBank (urn:lsid:zoobank.org:pub:XXXX). 
Systematic Paleontology

Order Plecoptera Burmeister, 1839

Suborder Arctoperlaria Zwick, 1973

Infra-order Systellognatha Enderlein, 1909

Superfamily Perloidea Latreille, 1802

Family Perlodidae Klapálek, 1912

Subfamily Isoperlinae Frison, 1942

Genus Isoperla Banks, 1906

Isoperla baltica $\mathbf{s p . ~ n o v . ~}$

(Figs. 1-4)

urn:1sid:XXXXXXX

Material. Holotype MNHN.F.A71350/BA4518, preserved in rectangular piece of amber measuring $15 \times 14 \times 7 \mathrm{~mm}$ embalmed in canada balsam.

Etymology. Named in reference to the origin of the amber piece (Baltic region). The specific epithet is to be treated as an adjective.

Diagnosis. Head without pale occipital mark, with darker area from labrum to lateral ocelli. Antennae with scape darker than pedicel and flagellum, scape more than twice as long a pedicel. Pronotum wider than long; pronotal disc with a median, pale, slightly hourglass-shaped stripe, rugosities present. Mid part of mesoscutum paler than sides. Forewing with Sc meeting RA after ra-rp crossvein; RP with two branches; MP and CuA not fused; $\mathrm{CuA}$ with three branches. Hind wing with reduced number of crossveins between $\mathrm{C}$ and Sc (only one), RP branches simple (without dichotomy); MA and MP simple; CuA with two branches; anal field large. Vesicle of sternum 8 absent. 10th tergum simple (without postero-medial cleft nor flaplike lobes), not fully covering genitalia 
ventrally. Paraprocts short and slightly sclerotized basally, anteriorly projected as a simple and more sclerotized tooth-shaped incurvation. Aedeagus (not fully everted) membranous. Basal cercomeres with crown of long setae along apical margin. Cerci with 17 cercomeres, each with long ventral seta, except for the two apical cercomeres.

Locality and horizon. Baltic amber, Baltic Sea region, Kalinigrad oblast, Poland / Russian Federation; Bartonian to Priabonian (ca. 34-38 Ma), late Eocene.

Description. Male. Body ca. $9.06 \mathrm{~mm}$ long. General body coloration dark-brown with lighter coloration on thorax; sternites and tergites slightly lighter than rest of body.

Head. Wider than long, ca. $1.01 \mathrm{~mm}$ long and $1.81 \mathrm{~mm}$ wide (eyes included), not sink under pronotum nor reduced. Compound eyes bulging laterally, ca. $0.54 \mathrm{~mm}$ long with a median indentation and covered posteriorly with a cuticular projection. Head with dark patch ranging from lateral ocelli and reaching labrum area, without coloration behind ocelli or between lateral ocelli. Gena with a toothlike projection located posteriorly to eyes; ocellar triangle isosceles, all ocelli of similar sizes; distance between ocelli slightly shorter than distance between lateral ocelli and eyes margin. Labial palps with four(?) palpomeres and maxillary palps with five palpomeres, both well-developed. Length of preserved maxillary palpomeres (in mm): I 0.08; II 0.12; III 0.44; IV 0.46; V at least 0.30. Length of preserved labial palpomeres: II 0.28; III 0.40; IV 0.34. Antenna long, filiform, with antennomeres tapering and elongating toward apex; scape more than twice as long as pedicel, pale yellow; pedicel and flagellum transparent due to preservation.

Thorax. Pronotum wider than long, ca. $1.08 \mathrm{~mm}$ long and $1.38 \mathrm{~mm}$ wide, with a median, pale slightly hourglass-shaped stripe; mid-dorsal pronotal suture well-impressed; rugosities irregular; raised pronotal disk; paler lateral margins. Legs, fore and mid legs shorter than hind leg, coloration hardly discernible; profemur with a conspicuous fringe of setae along anterior inner margin, ca. $1.22 \mathrm{~mm}$ long and ca. $0.36 \mathrm{~mm}$ of maximal width, protibia ca. $1.6 \mathrm{~mm}$ long and ca. $0.14 \mathrm{~mm}$ wide; protarsus ca. $0.55 \mathrm{~mm}$ long; mid femur ca. $1.42 \mathrm{~mm}$ long and ca. $0.38 \mathrm{~mm}$ wide, mesotibia ca. 1.82 
$\mathrm{mm}$ long and ca. $0.16 \mathrm{~mm}$ wide, mesotarsus ca. $0.62 \mathrm{~mm}$ long; hind femur ca. $2.32 \mathrm{~mm}$ long and ca. $0.36 \mathrm{~mm}$ wide, hind tibia ca. $2.64 \mathrm{~mm}$ long and ca. $0.24 \mathrm{~mm}$ wide, hind tarsus ca. $0.72 \mathrm{~mm}$ long; all tarsi with third tarsomere about three times longer than first tarsomere; tarsal claws simple; pulvilli setose.

Wings macropterous, hyaline; veins medium brown. Forewing at least $8.0 \mathrm{~mm}$ long and ca. $2.3 \mathrm{~mm}$ wide (measured in apical third). Numerous crossveins between $\mathrm{C}$ and Sc, at least seven; Sc long fused with RA in apical third of wing and after stout ra-rp crossvein; no sub-costal crossvein present (between Sc and R); at least two pterostigmatic veins present; RA simple; fork of R located before wing midlength; RP with two branches; rp-ma cross vein slightly postfurcal to ra-rp; $M$ long, fork located at posterior limit of medial wing length third, MA and MP simple; four mp-cu crossveins present (but number crossveins can be variable); $\mathrm{MP}$ and $\mathrm{CuA}$ not fused; $\mathrm{CuA}$ long with three branches; one mp-cua crossvein present; $\mathrm{CuP}$ straight reaching posterior wing margin before wing mid-length; five cua-cup crossveins present (one dichotomous); anal vein well operated originating from different points of 'anal cell'. Hind wings ca. $7.9 \mathrm{~mm}$ long, width not measurable since not fully preserved or folded on abdomen. Veins similarly configured as in forewing, except reduced number of crossveins between $\mathrm{C}$ and $\mathrm{Sc}$, no crossvein between $\mathrm{M}$ and $\mathrm{CuA}$; $\mathrm{CuA}$ with two branches; anal fold broad.

Abdomen ca. $4.40 \mathrm{~mm}$ long and $1.12 \mathrm{~mm}$ wide (width measure near midlength). Terga pale medially, except the two apical most tergites browner and with apical margin pale; with two dark patches located on each sides of tergal medial line, migrating from tergal base (near base of abdomen) to apical margin (near apex); tergal processes absent; 10th tergum simple, lacking posterior medial cleft or flaplike lobes. Sterna light brown, about twice as wide as long, posterior margin evenly rounded; vesicle not visible. Paraprocts slightly sclerotized basally, thin, slighlty recurved, broad basally, curved ventrad apically and tapering to broad points. Aedeagus not fully everted but mem- 
braneous. Cerci slender and pale brown, with 17 cercomeres, each with a long ventral seta except the two apical cercomeres.

Female unknown.

\section{Discussion}

\section{Systematic placement}

Using the key to families of adults Plecoptera of Fenoglio et al. (2021), our specimen keys out in Perlodidae because it possesses macropterous wings; posterior edge of hind wing forming, at level of $\mathrm{Cu}$ and $\mathrm{A}$, a notch delimiting anal lobe; no rudiments of gills between abdominal segments IX and $\mathrm{X}$; segment $\mathrm{X}$ visible; median region of abdominal sternites $\mathrm{X}$ unsclerotized in $\mathrm{X}$-shaped; abdominal sternite IX of male without bristle tuft; reduced mouthparts, viz. weak, elongated and flexible mandibles (if the mandibles are secondarily sclerotized, their shape is altered and they lack mola); long, filiform labial palps; rudimentary unsegmented gills on sides of thorax; anal region of forewing with a maximum of one row of transverse crossveins; large head; labial palpi visible in dorsal view; large hind wing anal area with five or more anal veins.

The review of the phylogeny of the Plecoptera has resulted in the definition of apomorphic characters for most of the families (Zwick, 2000) but many of the proposed characters are based on internal morphology and are hardly observable on fossil specimens. Nonetheless, the good preservation of specimens embedded in amber allows the observation of several key characters. Isoperla baltica sp. nov. has short first tarsomeres (apical tarsomeres about three times as long as first tarsomeres) (apomorphy of Systellognatha); a setose arolium (apomorphy of Systellognatha); forewing with numerous crossveins in costal field (plesiomorphy of Systellognatha), and rather stout and elongate labial palpi (plesiomorphy of Systellognatha) (Sroka et al., 2018). This combination of characters confirms our attribution to the Systellognatha. Some representatives of this Arc- 
toperlaria infra-order also retain the plesiomorphic character state 'euplantulae present on tarsi' (Sroka et al., 2018), but we could not confirm the presence of this character on our specimen.

The Systellognatha currently encompasses two superfamilies, namely the Perloidae (Perlodidae + Perlidae + Chloroperlidae) and the Pteronarcyoidea (Pteronarcyidae + Peltoperlidae + Styloperlidae). Our specimen does not belong to the family Pteronarcyidae because it has a reduced wing venation (vs. complete wing venation), a reduced number of crossveins (vs. numerous cross $^{-}$ veins), a simple vein MP in forewing (vs. branched in most Pteronarcyidae), vein RP simple (vs. with numerous branches) (Bethoux, 2005: fig. 8). Likewise, Isoperla baltica sp. nov. is not a Peltoperlidae since it lacks the shortened head strongly inserted into the angulate prothorax (autapomorphy of Peltoperlidae), a character found in extinct and extant peltoperlids (Zwick, 2000; Chen \& $\mathrm{Xu}, 2020)$. Two of the apomorphic characters used to define the family Styloperlidae (Uchida \& Isobe, 1989; Zwick, 2000) can only be observed on male specimens, viz. dense setal brush on male sternite nine and X-shaped sclerotization of male sternite 10 but a third character help to place female specimens viz. the reduction of spurs at the apex of tibia plus trifurcate setae as a third apomorphy (Uchida \& Isobe, 1989). Therefore, all the characters used to define the Styloperlidae are absent in Isoperla baltica sp. nov. since it also has strong tibial spurs.

Among the Perloidea, Isoperla baltica sp. nov. cannot be placed in the family Chloroperlidae since it lacks the following synapomorphies (Zwick, 2000): slender body; cerci distinctly shorter than the abdomen; oval pronota. Finally, the synapomorphies of the family Perlidae, all based on internatl morphology, are not observable on our specimen. However, our specimen cannot be placed in any of the two subfamilies composing the Perlidae, namely Perlinae and Acroneuriinae since its hemitergites 10 are not modified (vs. modified into anteriorly curved hooks in male Perlinae); it lacks hair brush on mesal areas of abdominal sternites (vs. present in Perlinae) and possesses unmodified paraproct (vs. transformed into anteriorly upcurved hooks in Acroneuriinae) (Zwick, 2000). Therefore, we place our specimen in the family Perlodidae that is not supported by apomor- 
phic character (Zwick, 2000). The Perlodidae are currently separated into the two subfamilies Perlodinae and Isoperlinae. Our specimen cannot be placed in the Perlodinae since it lacks the submental gills (putative apormorphy) (Ricker, 1952; Zwick, 2000). Accordingly, we place it within the Isoperlinae and we strengthen its placement observing the apomorphic characters of the subfamily viz. tergite 10 simple and paraprocts are simple upcurved hooks (Zwick, 2000). Currently, the family Isoperlinae comprises eight genera (DeWalt et al., 2020): Calliperla Banks, 1948; Cascadoperla Szczytko \& Stewart, 1979; Clioperla Needham \& Claassen, 1925; Cosumnoperla Szczytko \& Bottorff, 1987; Isoperla Banks, 1906; Kaszabia Raušer, 1968 and Mesoperlina Klapálek, 1921; and Parisoperla Huo \& Du, 2020. The genera Calliperla, Cascadoperla, and Clioperla share some characters with the Perlodinae (Szczytko \& Stewart, 1984) but our specimen cannot be placed in these genera (see below).

Isoperla baltica sp. nov. cannot be placed in the genus Clioperla since it has a broad ocellar area, nearly twice as broad as long (vs. plainly not twice as broad as long; Banks, 1947: 281; Szczytko \& Kondratieff, 2015: fig. 2.1); a different configuration of the forewing base, post-cubital field with crossveins and veins organized differently (Figs. 1, 2F, 3, 4A; Banks, 1947: figs. 3, 11); genal projections after eyes (vs. absent; Szczytko \& Kondratieff, 2015: fig. 2.1). Additionally, the presence of a cleft on 10th tergum, plus reduced, flat, mostly membranous paraprocts were proposed to differentiate the genus Clioperla (Szczytko \& Stewart, 1984: 262; Szczytko \& Kondratieff, 2015: fig. 2.2, 2.3). This combination of character is absent in our specimen.

Isoperla baltica sp. nov. differs from representatives of the genus Calliperla at least in possessing a third antennomere shorter than the second one (vs. third longer than second in Calliperla; Banks, 1947: fig. 44), pronotum less than twice as broad as long (vs. twice as broad as long; Banks, 1947: 279); apical maxillary palpomere normal, not shortened (vs. short; Banks, 1947: 279). The combination of characters: reduced, membranous epiproct and posterior recurved, flaplike lobes on 
tergum 10 was proposed to distinguished Calliperla (Szczytko \& Stewart, 1984: 262) but these characters are absent in our specimen.

Banks (1947) also proposed to separate the former subfamily Calliperlinae from the Isoperlinae, inter alia, based on the presence of long distinct bristles besides the short fringe on femora (Banks, 1947: fig. 23). However, this character seems to be present in many other genera belonging to the Isoperlinae (Banks, 1947: figs 22-25) questioning its diagnostic status. Additionally, the observation of this character can be difficult on fossil specimens due to the preservation, even for those preserved in amber since the setae can be damage during the fossilization process. Several wing venation characters have also been proposed to separate the 'Calliperlinae' and the Isoperlinae (e.g., angle between the anal veins, position of anal veins on anal cell) but the wing venation of the Plecoptera is not stable even at the intraspecific level (Liu et al., 2021). Therefore, splitting two subfamilies using these characters is questionable. Only the number of branches of RP, MA, MP, and $\mathrm{CuA}$ seems to be less variable (maybe due to the presence of trachea inside) and thus more useful for fossil species diagnosis.

Isoperla baltica sp. nov. cannot be placed in the genus Cascadoperla since it possesses short paraprocts without long basal stylus vs. elongate and with basal stylus (Szczytko \& Stewart, 1979: fig 230); tergum 10 lacks the apico-medial cleft vs. present (Szczytko \& Stewart, 1979: fig 230); the 10th tergum is flat without pointed lobes vs. posteriorly recurved with pointed lobes (Szczytko \& Stewart, 1984: 262); with a different coloration pattern on pronotum (Figs 1,3) (Szczytko \& Stewart, 1979: fig. 228); ocellar triangle is isosceles vs. equilateral (Szczytko \& Stewart, 1979: fig. 228). Szczytko \& Stewart (1979) also proposed the following coloration pattern, as useful to distinguish Cascadoperla from the other Isopterlinae: complete median dark stripe on head, darkest between ocelli. However, the coloration is hardly visible on our specimen preserved in amber and we prefer to avoid an over-interpretation on coloration characters that may be altered during the fossilization process. 
Isoperla baltica sp. nov. cannot be placed in the genus Cosumnoperla since it has a different configuration of the ocellar triangle viz. isosceles vs. equilateral in Cosumnoperla (Szczytko \& Bottorff, 1987: fig. 1; Bottorff, 2007); lacking a 10th tergal process vs. present (Szczytko \& Bottorff, 1987: fig. 3); paraproct more sclerotized vs. slightly sclerotized (Szczytko \& Bottorff, 1987: 66).

Isoperla baltica sp. nov. cannot be placed in the genus Kaszabia since it possesses cerci with dorsal fringe on basal segments (vs. lacking dorsal fringe on basal segments) and exceeding the length of the cercal segment (vs. not exceeding the length of the cercal segment) (Raušer, 1968; Judson \& Nelson, 2012: figs. 237, 238).

Isoperla baltica sp. nov. differs from representatives of the genus Mesoperlina since, at least, having a different configuration of the ocellar triangle viz. isosceles vs. equilateral (Koponen, 1949: fig. 18a); lacking subcostal crossveins vs. two, rarely more (Klapálek, 1921: 148; Zhiltzova, 1970: figs 1,6); having a different configuration of the 10th tergum (viz. without lobes nor cleft) vs. both present in Mesoperlina (Joost, 1970: fig. 9); cerci with different configuration of basal cercomeres (viz. second one smaller than third) vs. subequal (Joost, 1970: figs 9-10; Zhiltzova, 1970); apical sternite not as broad with a thin cuticular flange vs. broad and lacking cuticular flange (Joost, 1970: fig. 10); 10th sternite not covering all the genitalia vs. covering them (Joost, 1970: fig. 10); CuA with three branches vs. two or three (Koponen, 1949: fig. 18b; Zhiltzova, 1970).

Recently, the genus Parisoperla Huo \& Du, 2020 was described from China and placed in the Isoperlinae (Huo \& Du, 2020). However, Isoperla baltica sp. nov. differs from this genus in having a clearly different configuration of the ocellar triangle (wider than long, isosceles vs. as long as wide, equilateral in Parisoperla) (Huo \& Du, 2020: figs 6A, 10A); lacking a developed sclerotized process on male tergum 10 (Huo \& Du, 2020; fig. 1A-B); having a different organization of paraprocts (viz. less sclerotized basally, smaller, located close to cerci base and with a small upcurved projection vs. base conspicuously sclerotized, broad, clearly separated from cerci based and with a broad upcurved projection). 
Finally, the genus Isoperla has representatives lacking a cleft on the 10th tergum (Figs 1B, $2 \mathrm{H}, 3,4 \mathrm{C}$ ) and this configuration of the 10 th term is also present on our specimen. This genus is the most speciose within Isoperlinae and the only one with a putative fossil representative. The diagnosis of the genus is not well established since numerous species display patches of morphological characters. Its treatment as a single entity with a worldwide revision has not been realized. Banks (1906a: 175) proposed the following character to divide the genus Chloroperla, and create the genus Isoperla: "Isoperla for those forms having the median vein extending basally parallel to the radius". This character is present on our specimen (Figs 1, 2F, 3, 4A). The same years he also emended the diagnosis of the genus using wing venation characters (Banks, 1906b: 221): "the condition of the two lower branches or veins from the anal cell; in Isoperla, these two veins arise separately, but in Alioperla, these two veins unite before the cell, or rather, there is one forked vein instead of the two simple ones". In our specimen both branches are widely separated and only meet at the cell level (Figs 1, 3, 4B). Additionally, we notice a crossvein between these two veins (Figs 1, 3, 4A). Banks also provided a key to genera and proposed the character "Hind wings with but two cross-veins in cubital area, one near base, one near tip, small greenish or yellowish species" to separate Isoperla (Banks, 1906b: 224) while other authors (Needham \& Claassen, 1925: 49) used the character 'Hind wing without intercubital crossvein' in their key to separate the genus. This difference can be explained by the great variability in wing venations within the genus. The same authors provided a detailed diagnosis for the genus (Needham \& Claassen, 1925: 145) pointing the fact that Sc usually meet R; the presence of crossveins between $\mathrm{C}$ and $\mathrm{Sc}$; the presence of only one to three pterostigmatic veins in forewing (after the meeting point of $\mathrm{Sc}+\mathrm{R}$ ); the hind wing with a large folded anal area; the lack of cubital crossveins in hind wing. All these characters being present on our specimen, we decided to place it within the genus Isoperla. Similarly, Needham \& Claassen (1925: 145) described the cerci as: 'Abdomen with two long tails whose middle segments are three to five times as long as wide'; this state of character is found on our specimen strengthening our attribu- 
tion. Using the male genitalia, the same authors diagnosed the genus as possessing 'Ninth abdominal sternite much produced so as to extend at least to the tip of the abdomen; eighth sternite with a rounded, thickened knob on the hind margin; subanal lobes modified into slender upturned or recurved hooks; tenth tergite entire; supra-anal process not developed', all these characters seem to be present on our specimen except for the knob not well visible, if present (Figs. 1, 2G, 4D).

In light of all the data and comparisons, it seems difficult to place our specimen anywhere else than in the genus Isoperla. In addition, we did not find any character that would justify the creation of a new genus. Recently, a review of the genus Isoperla and of the subfamily Isoperlinae has been published to respond to the need to better define the subfamily and its constituting genera in the Nearctic ecozone (Szczytko \& Kondratieff, 2015). Following the key proposed by these authors, our specimen failed to key out after few couplets viz. it has a large body size, body length $>7.0$ $\mathrm{mm}$; forewing length $>8.0 \mathrm{~mm}$; abdominal color variable; sternum 7 without a lobe; paraprocts not flat and unsclerotized; macropterous; forewings $>6.0 \mathrm{~mm}$. But the following couplet deals with the shape of the male vesicle, which is absent on our specimen, preventing any correspondence with the Eastern Nearctic species. Our specimen also differs from all the known Isoperla by the combination of characters given in the diagnosis. We also provide a series of comparisons to help future works and illustrate some poorly visible characters in our specimen. Isoperla baltica sp. nov. differs from numerous Isoperla species in having short paraprocts (vs. long paraprocts in Isoperla eximia Zapekina-Dulkeit, 1975; Huo et al., 2020: fig. 6B), lacking ventral vesicle (vs. presence of vesicle in $I$. eximia; Huo et al., 2020: fig. 6D; Graf et al., 2020: fig. 1C); Sc meeting RA after ra-rp crossvein, vs. meeting before ra-rp (see Cao et al., 2020: fig. 2); RP with only two branches vs. more than two (see Cao et al., 2020: fig. 2); MP not meeting nor fused with CuA vs. meeting and partially fused with CuA (see Cao et al., 2020: fig. 2). Additionally, our specimen differs from all other species of Isoperla by its temporal range (Eocene vs. extant). 
Isoperla baltica sp. nov. differs from Isoperla succinica, the only fossil species in the genus, as follows (Hagen, 1856: 357): distance between posterior ocelli longer than distance between anterior and posterior ocelli, vs. posterior ocelli closer; a pronotum less than twice as broad as long vs. more than twice as broad as long; pronotum without sharp antero-lateral angle vs. with sharp antero-lateral corners; 8th cercomere more than twice as long as broad vs. barely twice as long as wide; last tergite lacking a median cleft vs. present.

\section{Wing venation plasticity and limitations in diagnoses of fossil Plecoptera}

The preservation of fossil specimens has always been a limitation to the description and classification of fossil species. Bodies and soft tissues being rarely preserved (even in amber), it restrains the interpretation and the observation of many key characters, leading paleo-entomologists to frequently use wing venation to separate species and study their relationships. This habit is efficient for groups with relatively stable wing venation (e.g. Hymenoptera, Diptera), but it fails to provide reliable support for many other groups with 'plastic' wing venation (e.g. Plecoptera, Neuropterida). To avoid this problem, entomologists working on modern fauna have more traditionally relied on the shape and arrangement of genitalia (providing several more stable characters and functioning as a 'key-lock' system), but these characters are rarely or insufficiently preserved on fossil specimens other than those in amber. Therefore, entomologists and paleo-entomologists diverge in their practice, each using the characters at disposal in the diagnoses of the clades: the genitalia (and to a lesser extent the wing venation) vs. mainly the wing venation (and to a lesser extent the genitalia), respectively.

Because of the wing venation variability in Plecoptera (e.g. Béthoux, 2005), the approach using the study of genitalia should be preferred (when possible) and combined with the study of wing venation. When this combination is impossible, documenting the intra-specific wing venation variation has to be done. To illustrate this point we figure a new specimen (MNHN.F.A71351; Figs 
5, 6) of the Middle Jurassic Pteroliriope sinitshenkovae Cui, Béthoux, Kondratieff, Shih \& Ren, 2016. As illustrated in Cui et al. (2016) the wing venation is highly variable in this taxon; even the main veins (viz. MA, MP, CuA) are configured differently depending on the observed specimens. On the new specimen, we observe several diagnostic characters (viz. area between R/RP and M basal to the fork of $\mathrm{M}$ of regular width, without crossveins; MA distinct from RP) supporting its taxonomic attribution but we also provide additional evidence of the wing venation variation (Fig. 6). These differences are observable for example in the number of crossveins between $\mathrm{M}$ and $\mathrm{CuA}$, and the shape of the vein M. Our interpretative line drawing (Fig. 6) illustrates the wide variation in wing venation, confirming the limits of wing venation, which is closely linked to the preservation of the specimen. Additionally, the specimen MNHN.F.A71351 has a pronotum with broadly rounded sides and posterior pronotal angles (Fig. 5). This suggests that our specimen may be better preserved on this part of the body than those figured in Cui et al. (2016), since they all have a poorly preserved quadrate pronotum.

Although the courses of several veins have been investigated in the order Plecoptera (Béthoux, 2005), additional questions deserve to be raised, especially the two following ones: (1) Does the Sc emits a second posterior branch after its fusion or contact point with $\mathrm{R}$ (as in Psocodea)? (2) How to differentiate pterostigmatic cross veins from the putative second branch of Sc? Answering these questions will undoubtedly help in interpreting the wing venation of fossil Plecoptera, which will come down to questioning the validity of certain fossil species described from compressions of isolated wings. This outcome is particularly expected for taxa described long ago and poorly preserved.

\section{Conclusion}

The description of Isoperla baltica sp. nov. clarifies the presence of the family Perlodidae in Baltic amber since the specimens of the two other described species of perlodid from this amber have been 
lost and were succinctly described. Isoperla baltica $\mathbf{s p . ~ n o v . ~ p r o v i d e s ~ a ~ r o b u s t ~ c a l i b r a t i o n ~ p o i n t ~ f o r ~}$ future phylogenetic analyzes and its description suggests that the perlodid diversity in Baltic amber is underestimated. Additionally, we illustrate a new specimen of Pteroliriope sinitshenkovae that emphasizes the variability of wing venation in some Plecoptera, underlining how important it is, when fossil Plecoptera are described from the wing venation alone, to have a large series of specimens to adequately account for this intraspecific variation. Finally, we highlight two questions to be addressed in future studies to help understanding the evolution of wing venation within the group.

\section{Acknowledgements}

We sincerely thank XXX anonymous referees for their useful comments on the first version of the paper, and XX (editor) for the useful remark on the first version of the manuscript.

\section{References}

Aleksandrova, G.N. \& Zaporozhets, N.I. (2008) Palynological characteristics of Upper Cretaceous and Paleogene deposits on the west of the Sambian Peninsula (Kaliningrad region), Part 2. Stratigraphical and Geological Correlations, 16, 528-539. https://doi.org/10.1134/ S0869593808050067

Banks, N. (1906a) On the perlid genus Chloroperla. Entomological News, 17, 174-175.

Banks, N. (1906b) Notes on the classification of the Perlidae. The Canadian Entomologist, 38, 221224. https://doi.org/10.4039/Ent38221-7

Banks, N. (1947) Some characters in the Perlidae. Psyche: A Journal of Entomology, 54, 266-291. https://doi.org/10.1155/1947/67653

Béthoux, O. (2005) Wing venation pattern of Plecoptera (Insecta: Neoptera). Illiesia, 1, 52-81. Available online: http://www2.pms-lj.si/illiesia/papers.html 
Béthoux, O., Cui, Y., Kondratieff, B., Stark, B. \& Ren, D. (2011) At last, a Pennsylvanian stemstonefly (Plecoptera) discovered. BMC Evolutionary Biology, 11, 248. https://doi.org/ $10.1186 / 1471-2148-11-248$

Bottorff, R.L. (2007) Cosumnoperla sequoia, a new species of stonefly from the Sierra Nevada, California (Plecoptera: Perlodidae: Isoperlinae). Illiesia, 3, 46-52. http://www2.pms-1j.si/illiesia/ Illiesia03-06.pdf

Burmeister, H. (1839) Handbuch der Entomologie, Reimer (publ.), Berlin, 1, 1-400.

Cao, Z., Wang, Y. \& Li, W. (2020) A new species of Isoperla (Plecoptera: Perlodidae) from China. Zootaxa, 4858, 251-260. https://doi.org/10.11646/zootaxa.4858.2.6

Caruso, C. \& Wichard, W. (2010) Overview and descriptions of fossil stoneflies (Plecoptera) in Baltic amber. Entomologie heute, 22, 85-97.

Chen, Z.T. \& Xu, C-P. (2020) First Peltoperlidae (Insecta: Plecoptera) from mid-Cretaceous Burmese amber. Cretaceous Research, 114, 104506. https://doi.org/10.1016/ j.cretres.2020.104506

Clauer, N., Huggett, J.M. \& Hillier, S. (2005) How reliable is the K-Ar glauconite chronometer? A case study of Eocene sediments from the Isle of Wight. Clay Minerals, 40, 167-176. https:// doi.org/10.1180/0009855054020163

Cui, Y., Béthoux, O., Kondratieff, B., Shih, C. \& Ren, D. (2016) The first fossil salmonfly (Insecta: Plecoptera: Pteronarcyidae), back to the Middle Jurassic. BMC Evolutionary Biology, 16, 217. https://doi.org/10.1186/s12862-016-0787-9

DeWalt, R.E., Maehr, M.D., Hopkins, H., Neu-Becker, U. \& Stueber, G. (2020) Plecoptera Species File Online. Version 5.0/5.0. [retrieval date]. http://Plecoptera.SpeciesFile.org

Enderlein, G. (1909) Klassification der Plecopteren sowie Diagnosen neuer Gattungen und Arten. Zoologischer Anzeiger, 34, 385-419. 
Fenoglio, S., Tierno de Figueroa, J.M. \& Fochetti, R. (2021) Chapitre 14. Ordre des Plecoptera (Plécoptères). pp. 341-350. In: Aberlenc, H.-P. (coord.). Les insectes du monde. Biodiversité, classification, clés de détermination des familles. Museo ed., Paris.

Frison, T.H. (1942) Descriptions, records and systematic notes concerning Western North American stoneflies (Plecoptera). The Pan-Pacific Entomologist, 18, 9-16.

Graf, W., Konar, M., Murányi, D., Orci, K.M. \& Vitecek, S. (2014) A new species of Isoperla (Insecta, Plecoptera) from the Karawanken, with considerations on the Southern Limestone Alps as centers of endemism. ZooKeys, 448, 27-36. https://doi.org/10.3897/zookeys.448.8509

Hagen, H. (1856) Die im Bernstein befindlichen Neuropteren der Vorwelt. In: Berendt, G.C., PictetBaraban, F.J. and Hagen, H. (eds). Die in Bernstein befindlichen organischen Reste der Vorwelt Gesammelt in Verbindung mit Mehreren Bearbeitetet und Herausgegeben, Gerhard, Berlin, 2, $41-126$.

Huo, Q-B., Chen, Z-N., Kong, X-B. \& Du, Y-Z. (2020) New records and a confirmation of three perlodid species in China, with additional notes and images of Rauserodes epiproctalis (Zwick, 1997) (Plecoptera: Perlodidae). Zootaxa, 4808, 455-474. https://doi.org/10.11646/ zootaxa.4808.3.3

Huo, Q-B. \& Du, Y-Z. (2020) A new genus and two new species of stoneflies (Plecoptera: Perlodidae) from Guizhou Province, China. Zootaxa, 4718, 470-480. https://doi.org/10.11646/ zootaxa.4718.4.2

Joost, W. (1970) Neue Steinfliegen aus Mittelasien (lnsecta; Plecoptera). Entomologische Nachrichten, 14, 113-121.

Jouault, C., Legendre, F., Grandcolas, P. \& Nel, A. (2021) Revising dating estimates and the antiquity of eusociality in termites using the fossilized birth-death process. Systematic Entomology (in press). https://doi.org.10.1111/syen.12477 
Judson, S.W. \& Nelson, C.R. (2012) A guide to Mongolian stoneflies (Insecta: Plecoptera). Zootaxa, 3541, 1-118. https://doi.org/10.11646/zootaxa.3541.1.1

Klapálek, F. (1912) Perlodidae. 1. Fam. Perlodidae. Collection Zoologique du Baron Edmond de Selys Longchamps, Catalogue systématique et descriptif, Bruxelles, 4, 1-61.

Klapálek, F. (1921) Plécoptères nouveaux. Annales de la Société Entomologique de Belgique, 61, $146-150$.

Koponen, J. (1949) Neue oder wenig bekannte Plecoptera. Annales Entomologici Fennici, Helsinki, $15,1-21$.

Kosmoswska-Ceranowicz, B., Kohlman-Adamska, A. \& Grabowska, I. (1997) Erste Ergebnisse zur Lithologie und Palynologie der bernsteinführenden Sedimente im Tagebau Primorskoje. Metalla, $66,5-17$.

Latreille, P.A. (1802) Histoire naturelle, générale et particulière des Crustacés et des Insectes. Ouvrage faisant suite aux œuvres de Leclerc de Buffon et partie du cours complet d'Histoire naturelle rédigé par C.S. Sonnini. T. 3-4, an X. Familles naturelles et genres. Paris, Dufart, 1-467 and $1-387$.

Lin, Q.B. (1992) Late Triassic insect fauna from Toksun, Xinjiang. Acta Palaeontologica Sinica, $31,313-335$.

Liu, F.-f., Li, W.-h., Cui, Y.-y. \& Béthoux, O. (2021) Tell a Styloperlidae from its wing venation: diagnostic traits of the family derived from a survey of intra-specific variability in Cerconychia livida Klapálek, 1913 and related species (Insecta: Plecoptera). Insect Systematics \& Evolution, 52, 97-109. https://doi.org/10.1163/1876312X-bja10001

Martynov, A.V. (1940) Permian fossil insects from Chekarda. Akademiya Nauk SSSR, Trudy Paleontologicheskogo Instituta, 11, 1-63.

Misof, B., Liu, S., Meusemann, K., et al. (2014) Phylogenomics resolves the timing and pattern of insect evolution. Science, 346, 763-767. https://doi.org/10.1126/science.1257570 
Needham, J.G. \& Claassen, P.W. (1925) A monograph of the Plecoptera or stoneflies of America north of Mexico. Entomological Society of America, the Thomas Say Foundation, 2, 1-397. https://doi.org/10.5962/bhl.title.6826

Raušer, (1968) Plecoptera. Ergebnisse der zoologischen Forschungen von Dr. Z. Kaszab in der Mongolei. Entomologische Abhandlungen: Staatliches Museum für Tierkunde in Dresden (Entomologische Abhandlungen) 34, 329-398.

Ricker, N. (1952) Systematic Studies in Plecoptera. Indiana University Publications Science Series, $18,1-200$.

Ritzkowski, S. (1997) K-Ar Altersbestimmungen der bernsteinführenden Sedimente des Samlandes (Palaeogen), Bezirk Kaliningrad. Metalla, 66, 19-23.

Ronquist, F., Klopfstein, S., Vilhelmsen, L., Schulmeister, S., Murray, D.L. \& Rasnitsyn, A.P. (2012) A total-evidence approach to dating with fossils, applied to the early radiation of the Hymenoptera. Systematic Biology, 61, 973-999. https://doi.org/10.1093/sysbio/sys058

Sadowski, E.M., Schmidt, A.R., Seyfullah L.J. \& Kunzmann, L. (2017) Conifers of the 'Baltic amber forest' and their palaeoecological significance. Stapfia, 106, 1-73.

Schubnel, T., Perdu, L., Roques, P., Garrouste, R., \& Nel, A. (2019). Two new stem-stoneflies discovered in the Pennsylvanian Avion locality, Pas-de-Calais, France (Insecta:'Exopterygota'). Alcheringa: An Australasian Journal of Palaeontology, 43, 430-435. https://doi.org/10.1080/03115518.2019.1569159

Sinitshenkova, N.D. (1987) Istopicheskoe razvitie vesiyanok. Akademiya Nauk SSSR, Trudy Paleontologicheskogo Instituta, 221, 1-142.

Sinitshenkova, N.D. (1990) New Mesozoic stoneflies from Asia. Paleontological Journal, 24, 6270.

Sinitshenkova, N.D. (1992) New upper Mesozoic stone flies from Yakutia (Insecta: Perlida = Plecoptera). Paleontological Journal, 26, 43-55. 
Sinitshenkova, N.D. (2018) New Stoneflies of the Suborder Nemourina Newman, 1853 (Insecta: Perlida $=$ Plecoptera) from the Middle Permian Deposits of the Kostovaty Locality, Udmurtia, Russia. Paleontological Journal, 52, 1374-1380. https://doi.org/10.1134/S0031030118120183

Spasojevic, T., Broad, G.R., Saaksjarvi, I.E., Schwarz, M., Ito, M., Korenko, S. \& Klopfstein, S. (2021) Mind the outgroup and bare branches in total-evidence dating: a case study of pimpliform Darwin wasps (Hymenoptera, Ichneumonidae). Systematic Biology, 70, 322-339. https://doi.org/ 10.1093/sysbio/syaa079

Sroka, P., Staniczek, A.H. \& Kondratieff, B.C. (2018) 'Rolling' stoneflies (Insecta: Plecoptera) from mid-Cretaceous Burmese amber. PeerJ, 6, e5354. https://doi.org/10.7717/peerj.5354

Standke, G. (2008) Bitterfelder Bernstein gleich Baltischer Bernstein? - Eine geologische RaumZeit- Betrachtung und genetische Schlußfolgerungen. Exkursionsführer und Veröffentlichungen der Deutschen Gesellschaft für Geowissenschaften, Hannover, 236, 11-33.

Szczytko, S.W. \& Bottorff, R.L. (1987) Cosumnoperla hypocrena, a new genus and species of western Nearctic Isoperlinae (Plecoptera: Perlodidae). Pan-Pacific Entomologist, 63, 65-74.

Szczytko, S.W. \& Kondratieff, B.C. (2015) A review of the Eastern Nearctic Isoperlinae (Plecoptera: Perlodidae) with the description of twenty-two new species. Monographs of Illiesia, 1, 1-289. Available online: http://www2.pms-lj.si/illiesia/monographs/number 1.pdf

Szczytko, S.W. \& Stewart, K.W. (1979) The genus Isoperla (Plecoptera) of western North America; holomorphology and systematics and a new stonefly genus Cascadoperla. Memoirs of the American Entomological Society, 32, 1-120.

Szczytko, S.W. \& Stewart, K.W. (1981) Reevaluation of the genus Clioperla. Annals of the Entomological Society of America, 74, 563-569. https://doi.org/10.1093/aesa/74.6.563

Szczytko, S.W. \& Stewart, K.W. (1984) Descriptions of Calliperla Banks, Rickera Jewett, and two new Western Nearctic Isoperla Species (Plecoptera: Perlodidae). Annals of the Entomological Society of America, 77, 251-263. https://doi.org/10.1093/aesa/77.3.251 
Uchida, S. \& Isobe, Y. (1989) Styloperlidae, stat. nov. and Microperlinae subfam. nov. with a revised system of the family group Systellognatha. Spixiana, 12, 145-182.

van Dijk, D.E. \& Geertsema, H. (2004) A new genus of Permian Plecoptera (Afroperla) from KwaZulu-Natal, South Africa. African Entomology, 12, 268-270. https://hdl.handle.net/10520/ EJC32596

Vea, I.M. \& Grimaldi, D.A. (2016) Putting scales into evolutionary time: the divergence of major scale insect lineages (Hemiptera) predates the radiation of modern angiosperm hosts. Scientific Reports, 6 (23487), 1-11. https://doi.org/10.1038/srep23487

Wang, Y, Engel, M.S., Rafael, J.A., Wu, H., Rédei, D., Xie, Q., Wang, G., Liu, X. \& Bu, W. (2016) Fossil record of stem groups employed in evaluating the chronogram of insects (Arthropoda: Hexapoda). Scientific Reports, 6 (38939), 1-12. https://doi.org/10.1038/srep38939

Weitschat, W. \& Wichard, W. (2010) Baltic amber. In: Penney, D. (Ed.), Biodiversity of fossils in amber from the major world deposits. Siri Scientific Press, Manchester, pp. 80-115.

Wipfler, B., Letsch, H., Frandsen, P.B., Kapli, P., Mayer, C., Bartel, D., Buckley, T.R., Donath, A., Edgerly-Rooks, J.S., Fujita, M., Liu, S., Machida, R., Mashimo, Y., Misof, B., Niehuis, O., Peters, R.S., Petersen, M., Podsiadlowski, L., Schütte, K., Shimizu, S., Uchifune, T., Wilbrandt, J., Yan, E., Zhou, X \& Simon, S. (2019) Evolutionary history of Polyneoptera and its implications for our understanding of early winged insects. Proceedings of the National Academy of Sciences USA, 116, 3024-3029. https://doi.org/10.1073/pnas.1817794116

Zhiltzova, L.A. 1970. A revision of the stoneflies of the genus Mesoperlina Klap. (Plecoptera, Perlodidae) from Soviet Central Asia. Entomologischeskoe Obozrenie, 49, 355-363.

Zwick, P. (1973) Insecta: Plecoptera. In: de Gruyter, W. (Ed.), Phylogenetisches System und Katalog. Das Tierreich, Berlin \& New York, pp. 465.

Zwick, P. (2000) Phylogenetic system and zoogeography of the Plecoptera. Annual Review of Entomology, 45, 709-746. https://doi.org/10.1146/annurev.ento.45.1.709 
Figure caption:

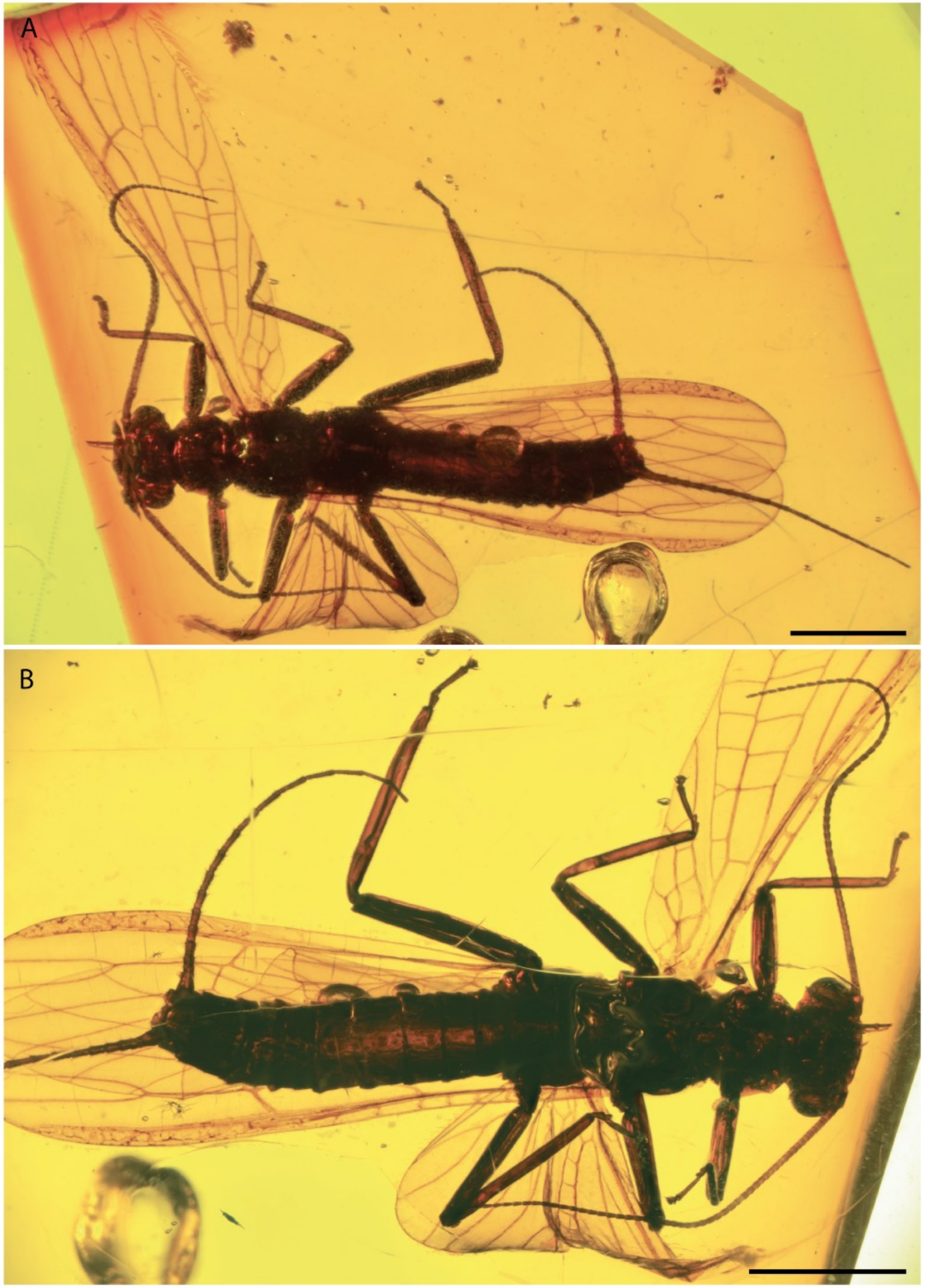


FIGURE 1. Isoperla baltica sp. nov. Holotype MNHN.F.A71350/BA4518. (A) Habitus in dorsal view. (B) Habitus in ventral view. Scale bars $=2 \mathrm{~mm}$.

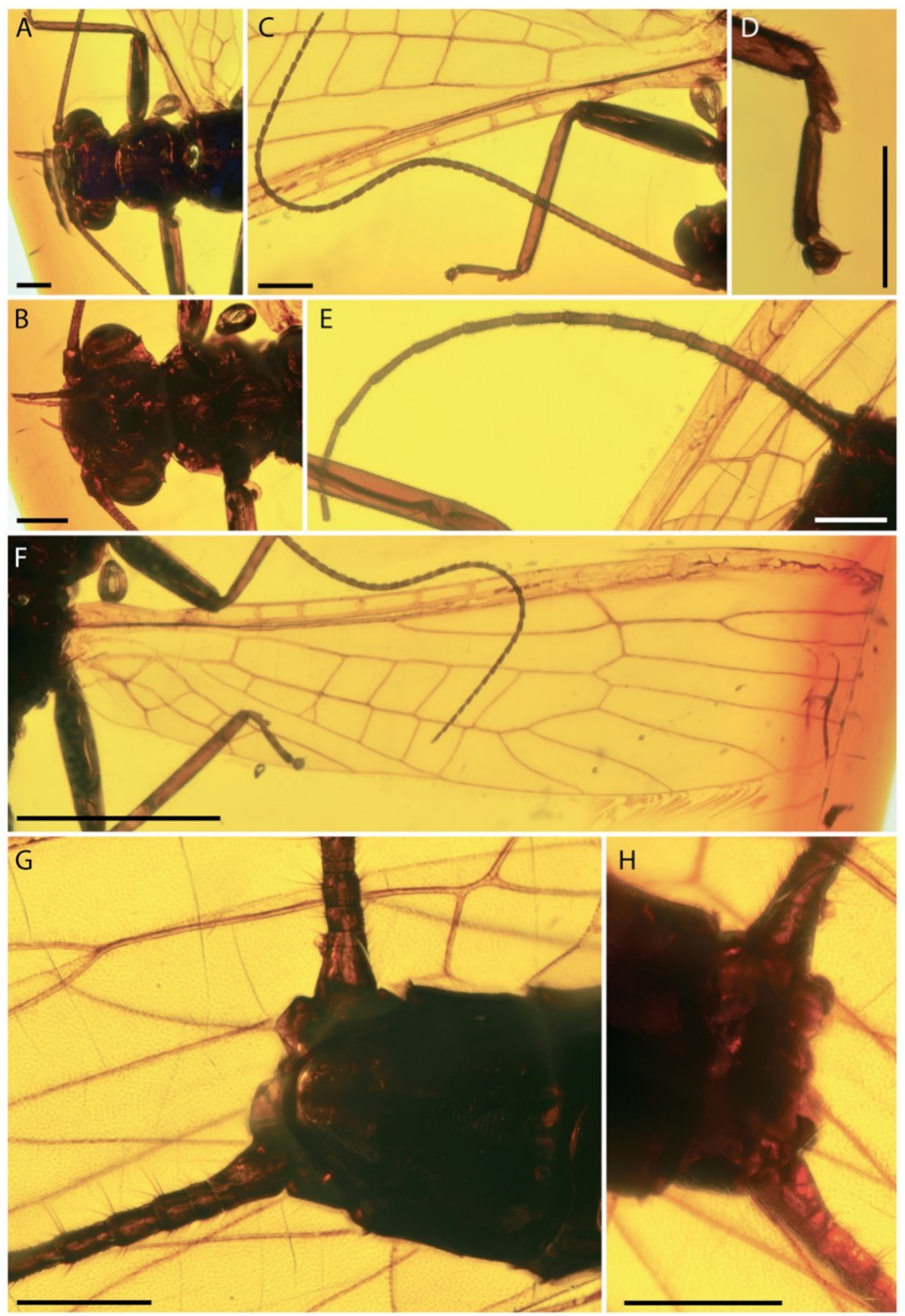


FIGURE 2. Detailed view of Isoperla baltica sp. nov. Holotype MNHN.F.A71350/BA4518. (A)

Dorsal view of head and pronotum. (B) Right antenna. (C) Head in ventral view. (D) Tarsus. (E)

Right cerci. (F) Right forewing. (G) Apical part of abdomen in ventral view. (H) Apical part of abdomen in dorsal view. Scale bars: $0.5 \mathrm{~mm}(\mathrm{~A}-\mathrm{E}, \mathrm{G}, \mathrm{H}) ; 2 \mathrm{~mm}(\mathrm{~F})$.

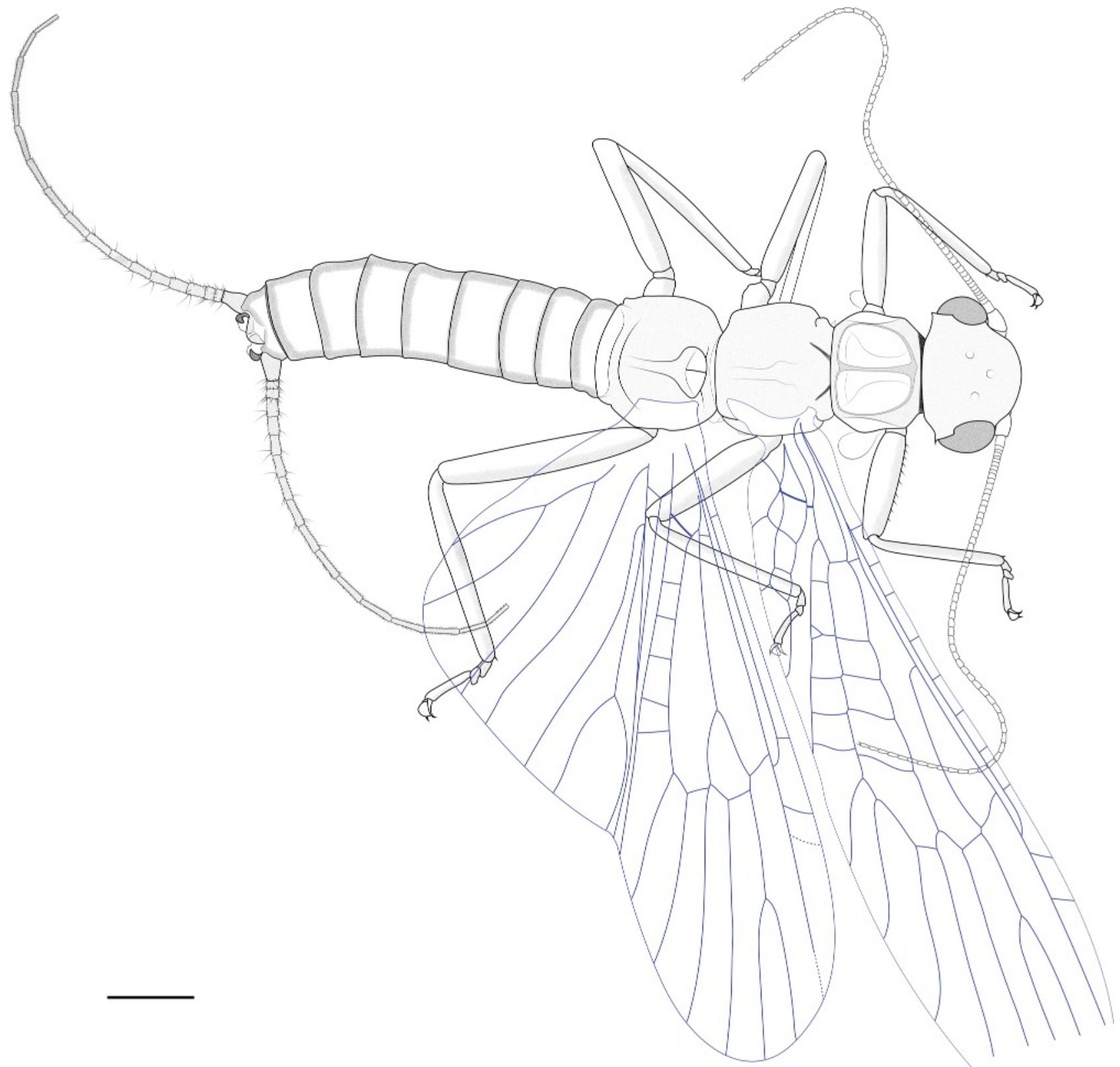


FIGURE 3. Interpretative drawing of habitus of Isoperla baltica sp. nov. Holotype MNHN.F.A71350/BA4518. Scale bar $=1 \mathrm{~mm}$.

A
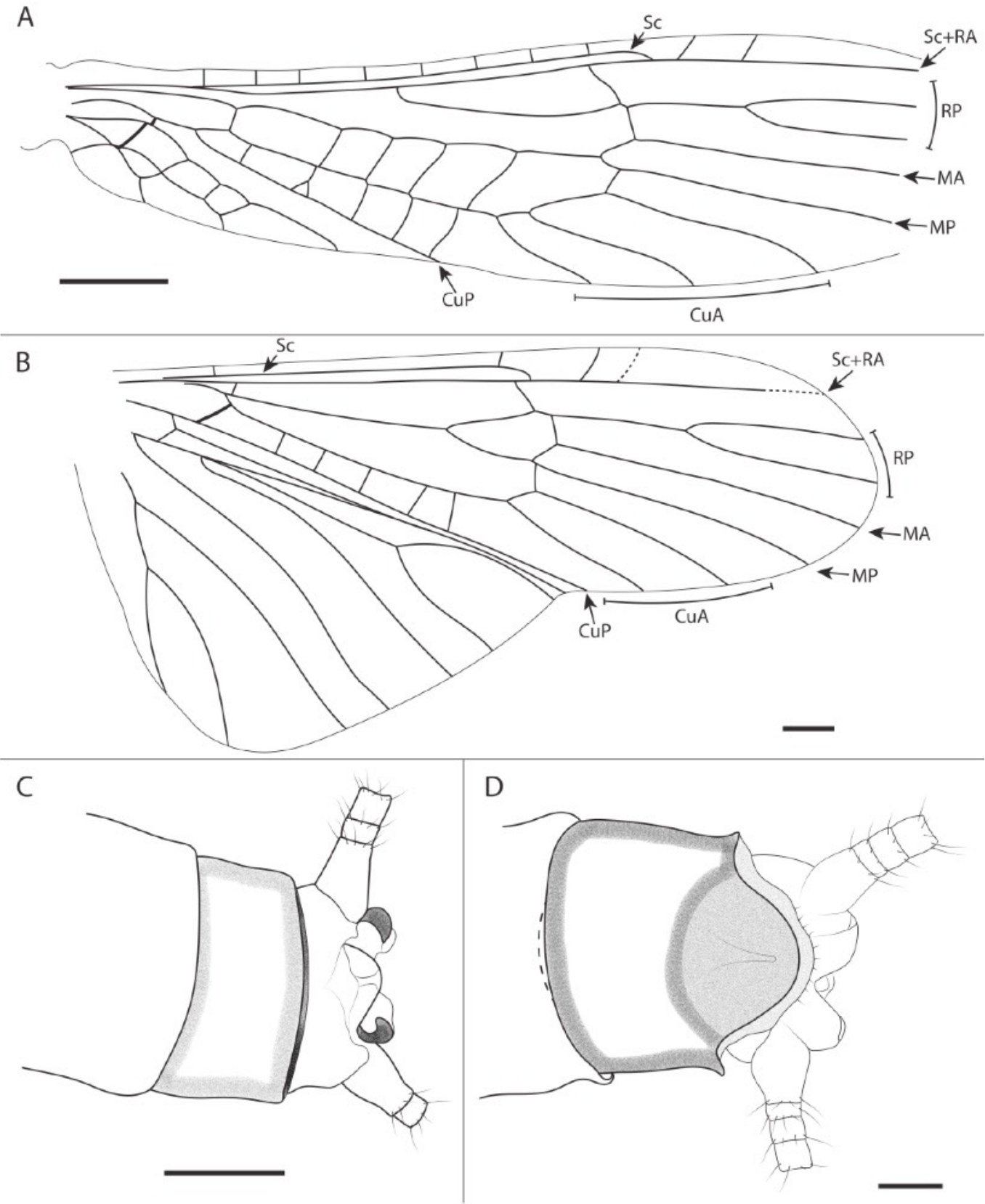
FIGURE 4. Interpretative drawing of Isoperla baltica sp. nov. Holotype MNHN.F.A71350/ BA4518. (A) Forewing with veins nomenclature added. (B) Hind wing. (C) Apex of abdomen in dorsal view. (D) Apex of abdomen in ventral view. Scale bars: $1 \mathrm{~mm}(\mathrm{~A}), 0.5 \mathrm{~mm}(\mathrm{~B}, \mathrm{C}) ; 0.25$ $\mathrm{mm}(\mathrm{D})$.

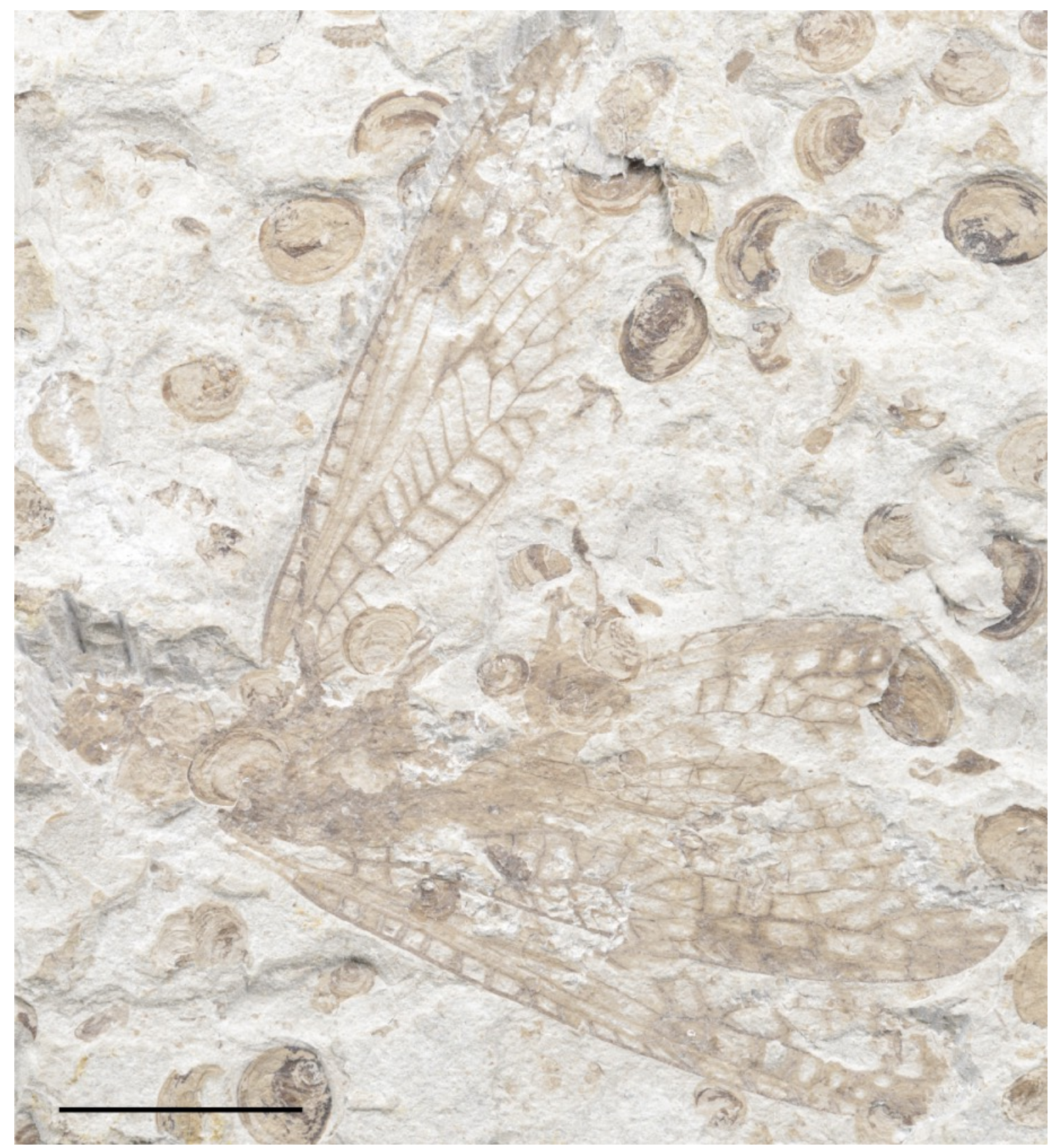

FIGURE 5. Photograph of Pteroliriope sinitshenkovae Cui, Béthoux, Kondratieff, Shih \& Ren, 2016 Specimen MNHN.F.A71351. Scale bar $=1 \mathrm{~cm}$. 


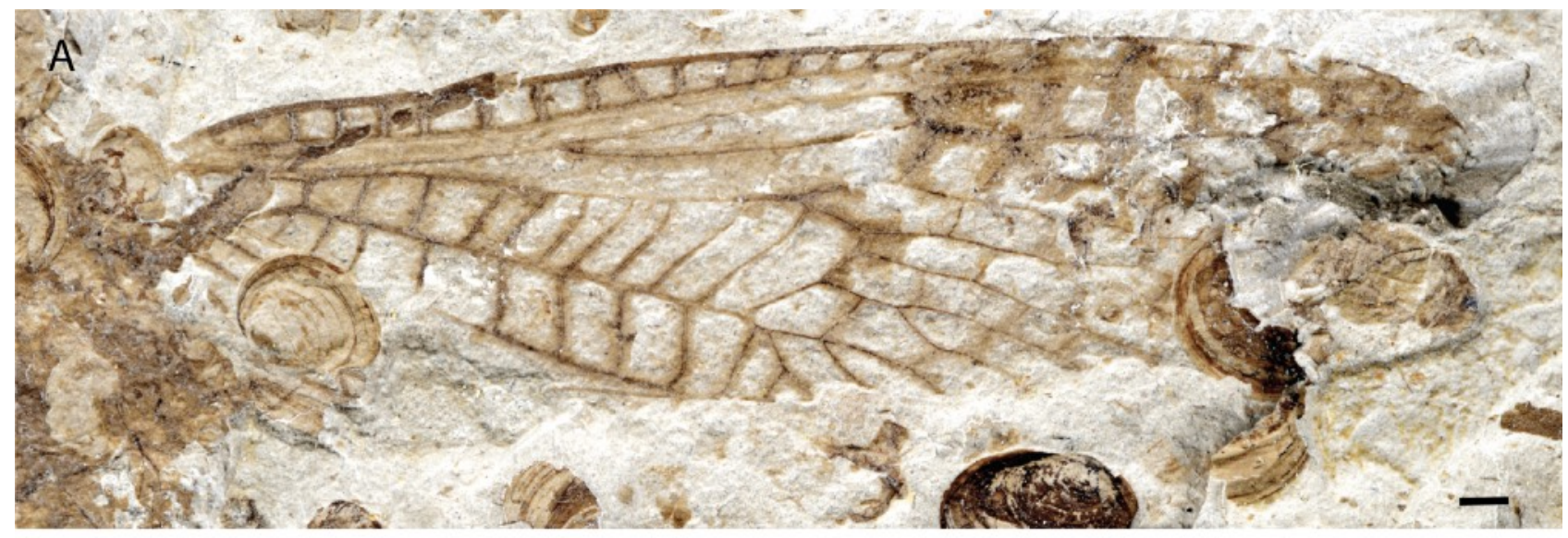

B

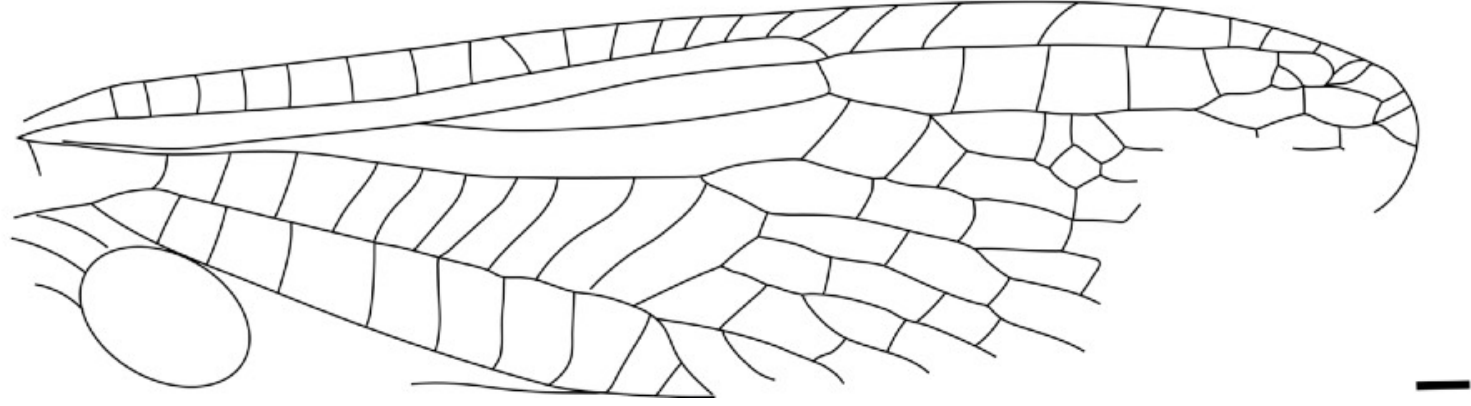

FIGURE 6. Pteroliriope sinitshenkovae Cui, Béthoux, Kondratieff, Shih \& Ren, 2016 Specimen MNHN.F.A71351. (A) Photograph of right forewing. (B) Interpretative line drawing of fore wing venation. Scale bars $=1 \mathrm{~mm}$. 